\title{
The Enlightenment on English Listening Teaching by Cognitive Process of Metaphor
}

\author{
Zhishang Yang \\ Department of Foreign Languages, Changsha Medical University, Changsha 413000, China \\ 284204813@qq.com
}

Keywords: concept of metaphor; English listening teaching; image schema; teaching enlightenment

\begin{abstract}
In English teaching, there are more and more studies on metaphor theory. However, there are few studies on the cognitive process of metaphor in the English listening teaching, which cannot guide the listening teaching for teachers effectively. Therefore, this paper mainly discusses the enlightenment of metaphor concept and image schema and metaphorical cognitive process for English listening teaching.
\end{abstract}

\section{Introduction}

With the rise of the concept of quality-oriented education, the teacher in English teaching is more and more concerned with the cultivation of students' comprehensive quality, namely, training students' English listening ability, reading ability, writing ability, and English speaking ability. Among these, listening ability is an important quality and is an important premise for them to interact and communicate with others through English. If one owns excellent listening ability, he can effectively understand its real meaning. Thus, the teacher needs to apply good teaching method to cultivate the students' English listening ability and metaphorical thoughts, which promotes the quality of the English teaching.

\section{Metaphorical Concept and Image Schema}

Metaphor is a cognitive concept which has the following functions. Firstly, we can observe the nature well and improve the quality and level of observation in good metaphors. Secondly, humans can conceptualize cognitive experience in good metaphors. Thirdly, metaphor is a sort of creative thinking formed in the long-term production and life of mankind, which can effectively arrange the existing knowledge and experience and create new logic things. (This can be reflected effectively from table 1). From the above expression of metaphorical function, people define the metaphor as follows: Human use their experience in a certain field to perceive complex, invisible, and unfamiliar things that have abstract concept. Through the effective application of metaphor, people can be inspired better to think about related knowledge and structure.

To better study the metaphorical cognitive process, someone has created the image schema. Through the source domain and target domain, the effective composition is carried out, and then a correspondence of validity is established to better map the internal structure. For example, in the sentence "Time is money", "time" is the target domain and "money" is the source domain, which establishes the validity of the image schema[1]. 
Table 1 Metaphorical function

\begin{tabular}{ll}
\hline Metaphorical type & Meaning \\
\hline Observation of the nature & Improvement of the observing quality \\
acquisition of experience & Conceptualization of cognitive \\
Production and living & experience \\
Creative thoughts and creative and new \\
logic things
\end{tabular}

\section{The Enlightenment on English Listening Teaching by Cognitive Process of Metaphor}

In English listening teaching, the effective application of metaphor by teachers can stimulate students interest in learning, better cultivate their metaphorical way of thinking, build new learning mind maps of English listening, and provide important implications for the students to learn English in the future.

\section{Vocabulary teaching and listening teaching}

English teachers need to apply various effective ways to train students' listening ability, improve their English listening level, and lay a good foundation for their future English learning and English application with high quality in life practice. In different situations, teachers need to set up effective scene words and carry out targeted teaching. A significant part of it is starting from the English vocabulary, which enables students to learn a large number of English words.

Teachers need to strengthen communication, and the communication skills enable students accumulate a large amount of English vocabulary in a given language environment.With sufficient vocabulary, teachers can better understand the meaning of sentences in listening teaching and innovate their expression. Meanwhile, teachers need to better help students to establish new learning mode, grasp the meaning of the vocabulary and avoid mistakes based on the accumulation of English vocabulary. Besides, teachers also need to better help students to analyze the relationship between English words and meaning, actively introduce the teaching method of metaphorical cognition process, and train the student to gradually develop a metaphorical thinking in listening teaching and can make a correct judgment and selection for vocabulary. (The main feature can reflected from the table 2)

Table 2 Main features of teachers' metaphorical teaching of vocabulary

\begin{tabular}{cc}
\hline $\begin{array}{c}\text { Features of metaphorical teaching of } \\
\text { vocabulary }\end{array}$ & Main meaning \\
\hline $\begin{array}{c}\text { Specific language circumstance } \\
\text { Building new teaching mode }\end{array}$ & $\begin{array}{c}\text { Accumulation of many English words } \\
\text { Analysis of the relationship between } \\
\text { words and meaning }\end{array}$ \\
$\begin{array}{l}\text { Extension of vocabulary meaning } \\
\text { Cultivating students to develop the } \\
\text { metaphorical thoughts }\end{array}$ \\
\hline
\end{tabular}

For example, the word "orientation" has many meanings. Specifically speaking, first, it means the direction, orientation and goal (of organization, state, etc.). Second, it means direction and aim. Third, it means choice and attitude (of someone's preference and belief). Fourth, it means positioning force (of psychoanalysis, psychology). Fifth, it means orientation, position, and direction (from the angle of chemical). Sixth, it refers to the ability (from the angle of zoology, specially the bird homing). Seventh, it means orientation(from the angle of biology). Eighth, it refers to the environmental judgment and direction judgment. Ninth, it refers to the orientation (of buildings and various buildings). Lastly, it means training, practice and environmental introduction (of diverse courses training, pre-work training, etc ). Among them, the direction and goal are the original meaning of “orientation”, and others are metaphorical meanings.

In English listening teaching practice, teachers need to cultivate and encourage students to to expand their vocabulary on the basis of understanding the basic meaning of words. Besides, teachers also should encourage students to understand other implications of the words, and then to accumulate 
words effectively and fully understand the phenomenon of polysemy. Through this sort of teaching mode, on the one hand, teachers can better arouse the students' learning enthusiasm. On the other hand, teachers can make them to have a deeper understanding of the metaphorical meaning among words, gradually form a metaphorical thinking, expand their vocabulary, and improve the English listening ability.

\section{Culture and listening teaching}

Culture is the important carrier of language learning, and in particular historical and cultural environment, the language of unique style is formed. Thus, in English listening teaching, teachers need to think effectively about these different types of cultures and lay a good foundation for improving the quality of listening teaching. Britain is a country that is inseparable from the sea, which has developed fishery resources and deeply reflects the signs of coastal culture. Therefore, "fish" is a relatively symbolic word in English. For instance, the sentence "neither fish nor fowl", it can be interpreted as "non-donkey non-horse" in Chinese with a very typical agricultural culture. In some other countries, such as New Zealand and Australia, some animals have a meaning in some languages. Therefore, teachers need to have a deep appreciation of these special types of vocabulary in listening teaching, and enhance the students' understanding ability. (The main contents can be reflected by the table 3)

Table 3 Extended meaning of English vocabulary

\begin{tabular}{lll}
\hline English vocabulary & Original meaning & Extended meaning \\
\hline dingo & pye-dog in Australia & cheater \\
Nightingale & nightingale & informer \\
\hline
\end{tabular}

The above words have the extended meaning, and the lack of understanding of their culture can lead to misunderstanding of the vocabulary and cause English hearing impairment. Thus, $\mathrm{n}$ English listening teaching, the effective integration of English culture will improve the teaching level.

\section{Pronunciation and listening teaching}

In English listening teaching, pronunciation is an important part. In English language communication, even there are some same words, the application of different languages means different meanings. (The specific examples can be reflected by the table 4)

Table 4 Different pronunciations with different meanings

\begin{tabular}{|c|c|c|}
\hline Same sentence & $\begin{array}{l}\text { The meaning of rising } \\
\text { tone }\end{array}$ & $\begin{array}{l}\text { The meaning of falling } \\
\text { tone }\end{array}$ \\
\hline $\begin{array}{l}\text { Have you brought my } \\
\text { book? }\end{array}$ & $\begin{array}{l}\text { Read aloud by using } \\
\text { rising tone }\end{array}$ & $\begin{array}{l}\text { Read aloud by using } \\
\text { falling tone }\end{array}$ \\
\hline $\begin{array}{l}\text { Have you brought my } \\
\text { book? }\end{array}$ & $\begin{array}{l}\text { Have you already } \\
\text { brought my book? }\end{array}$ & $\begin{array}{l}\text { I want the book and I } \\
\text { have already gotten it. }\end{array}$ \\
\hline
\end{tabular}

From the above examples, it can be seen that all sentences are " Have you brought my book?". However, in different voice environments, different meanings can be created. It can be seen that intonation and speech have important metaphorical features, and different expressions can form different meanings. Hence, English teachers need to guide students to correctly apply the English phonetics, avoiding the failure of communication in the future listening teaching, which lays a good foundation for the future learning and development[2].

\section{Conclusion}

In English listening teaching, the cognitive process of metaphor is of great significance in that it can help teachers to better understand the real meaning of English vocabulary and effectively lead students to memorize and apply these words through the implications of these words. And teachers can promote students to express these words flexibly in daily life, establishing the new corresponding relationship and improving the English comprehensive quality. 


\section{References}

[1]Macarthur F. Overt and covert uses of metaphor in the academic mentoring in English of Spanish undergraduate students at five European universities[J]. Review of Cognitive Linguistics, 2016, 14(1):23-50.

[2]Thellefsen M, Thellefsen T, Sørensen B. The fallacy of the cognitive free fall in communication metaphor: A semiotic analysis[J]. Library Trends, 2015, 63(1):512-527. 